\title{
HTLV-1 Associated Myelopathy in Canada
}

\author{
Christopher Power, Brian G. Weinshenker, Gregory A. Dekaban, G.C. Ebers, \\ Gordon S. Francis and George P.A. Rice
}

\begin{abstract}
We report the clinical and laboratory findings of six Canadian patients with progressive myelopathy associated with HTLV-I infection. The diagnosis was suspected on clinical grounds and supported by serological studies and positive gene amplification. Only five had emigrated from an area endemic for HTLV-1 infection. Tropical spastic paraparesis should be considered in all patients with myelopathy, even those without standard serological markers of HTLV-1 infection. The pathogenesis of this condition and the serological and molecular biological means by which this diagnosis can be made are reviewed.

RÉSUMÉ: La myélopathie associée à l'infection HTLV-1 au Canada Nous rapportons les données cliniques et au laboratoire chez six patients canadiens atteints de la myélopathie progressive associée à l'infection HTLV-1. On a soupçonné le diagnostic selon les critères cliniques, appuyés d'études sérologiques et de l'amplification positive de gènes. Seulement cinq patients avaient emigré d'un lieu où l'infection HTLV-l était endémique. On devrait considérer la paraparésie spastique tropical comme diagnostic chez tous les patients atteints de myélopathie, même ceux qui manquent les marqueurs ordinaires sérologiques de l'infection HTLV-1. La pathogenèse de cette maladie et les moyens sérologiques et bilogique moléculaire de faire ce diagnostic sont discutés.
\end{abstract}

Can. J. Neurol. Sci. 1989; 16:330-335

Tropical spastic paraparesis (TSP) is a chronic progressive myelopathy. It was first consolidated in 1956 by Cruickshank although similar cases were described in the last century. ${ }^{1}$ It has been reported from the Caribbean basin, ${ }^{2}$ Colombia, ${ }^{3}$ the Seychelles, ${ }^{4}$ the southeastern United States, ${ }^{5}$ and Japan. ${ }^{6}$ HTLV-1 has recently been implicated as the cause of TSP. 7.8 The recently described association of this virus with MS remains controversial. ${ }^{9}$

We have identified six Canadian patients with TSP, which was suspected on clinical grounds and confirmed by serological and molecular biological techniques.

\section{CASE Reports}

\section{Patient I}

A 44-year-old black woman, born in Trinidad, immigrated to Canada in 1965. At age 34 she developed insidiously progressive weakness of all limbs and hyperesthesia over the legs and abdomen. Within six years she required a walker. Lower leg spasms, constipation and urinary incontinence were also described. She had had multiple sexual partners of Caribbean origin while residing in New York from 1976 to 1980. No family history of neurological disease was apparent. The patient had not received blood transfusions.
Neurological examination revealed severe spasticity in all limbs, mild hip flexor weakness and bilateral extensor plantar responses. Mild wasting was present in the hands. The sensory examination was normal.

\section{Patient 2}

This 21-year-old male, also from Trinidad, immigrated to Canada in 1974. He developed insidious bilateral leg weakness at age 13. Urgency incontinence, chronic low back pain and leg spasms were minor problems. There was no family history of neurological disorders. The patient denied previous sexual contact or blood transfusions. Physical examination revealed mild wasting of the distal arm and leg muscles and generalized spasticity. Strength was moderately diminished in the lower extremities in an upper motor neuron distribution. Deep tendon reflexes were hyperactive and the gait was spastic. Mild impairment in pinprick and vibration perception was evident in the feet and hands.

\section{Patient 3}

This 41 -year-old black Guyanese male immigrated to Canada in 1975. He presented with impotence at age 33. At age 36, he developed urinary urgency, frequency and incontinence. He was found to have urinary retention and required intermittent catheterization. He complained of low back pain, and he stumbled occasionally.

Bladder and sexual function worsened, and he developed increasing weakness, greater in the left leg. He denied sensory symptoms. His family history was unremarkable for neurological disease. He reported multiple sexual partners and two episodes of gonorrhea.

From the Department of Clinical Neurological Sciences, and Robarts Research Institute, University of Western Ontario, University Hospital, London and the Montreal Neurological Hospital, Montreal Received March 29, 1989. Accepted in final form May 27, 1989

Reprint requests to: G.P.A. Rice, Department of Clinical Neurological Sciences, University of Western Ontario, University Hospital, 339 Windermere Rd., London, Ontario, Canada N6A 5A5 
Physical examination revealed mild atrophy of the small muscles of the feet with spasticity in all limbs. Strength was mildly diminished in the limbs. Deep tendon reflexes were generally brisk with bilateral extensor plantar responses. Coordination, gait and sensory function were normal.

\section{Patient 4}

This 48-year-old woman had a 14 year history of deteriorating mobility, associated with a burning feeling in her lower extremities, urgency of micturition and constipation. She became chairbound within a decade of the onset of her symptoms. No other neurological symptoms were described.

She had been born in Jamaica and immigrated to Canada at age 26. She had had gonorrhea once; blood transfusions were not described.

Neurological examination revealed a moderately severe spastic quadriparesis, with brisk reflexes and extensor plantar responses. She could not walk. Vibration was mildly impaired in the legs. The rest of the examination was normal.

\section{Patient 5}

This 45-year-old housewife came to Canada from Chile 14 years ago. She described a four year history of progressive leg weakness, slightly worse on the right side. She could walk only 300 metres. Back and leg pain were moderately severe as was urgency of micturition. The family history was not contributory; the extraction was Spanish.

A few beats of horizontal nystagmus were present, but the remainder of the examination was highlighted by a spastic paraparesis, hyperreflexia and extensor plantar responses. Sensory findings were minimal.

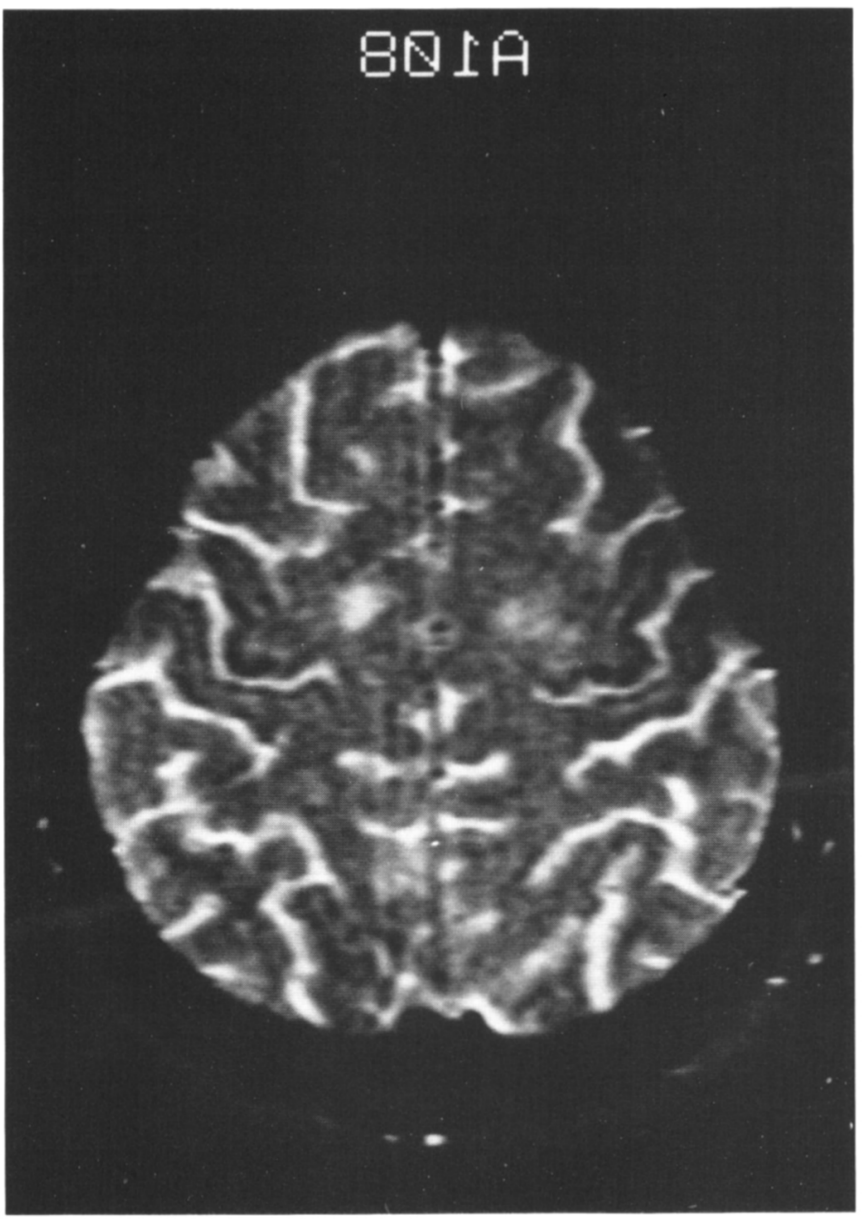

$\mathbf{R}$

Figure I - Cranial Scan of Patient I. (MRI, T2 image) Periventricular white matter lesions have an increased signal intensity.

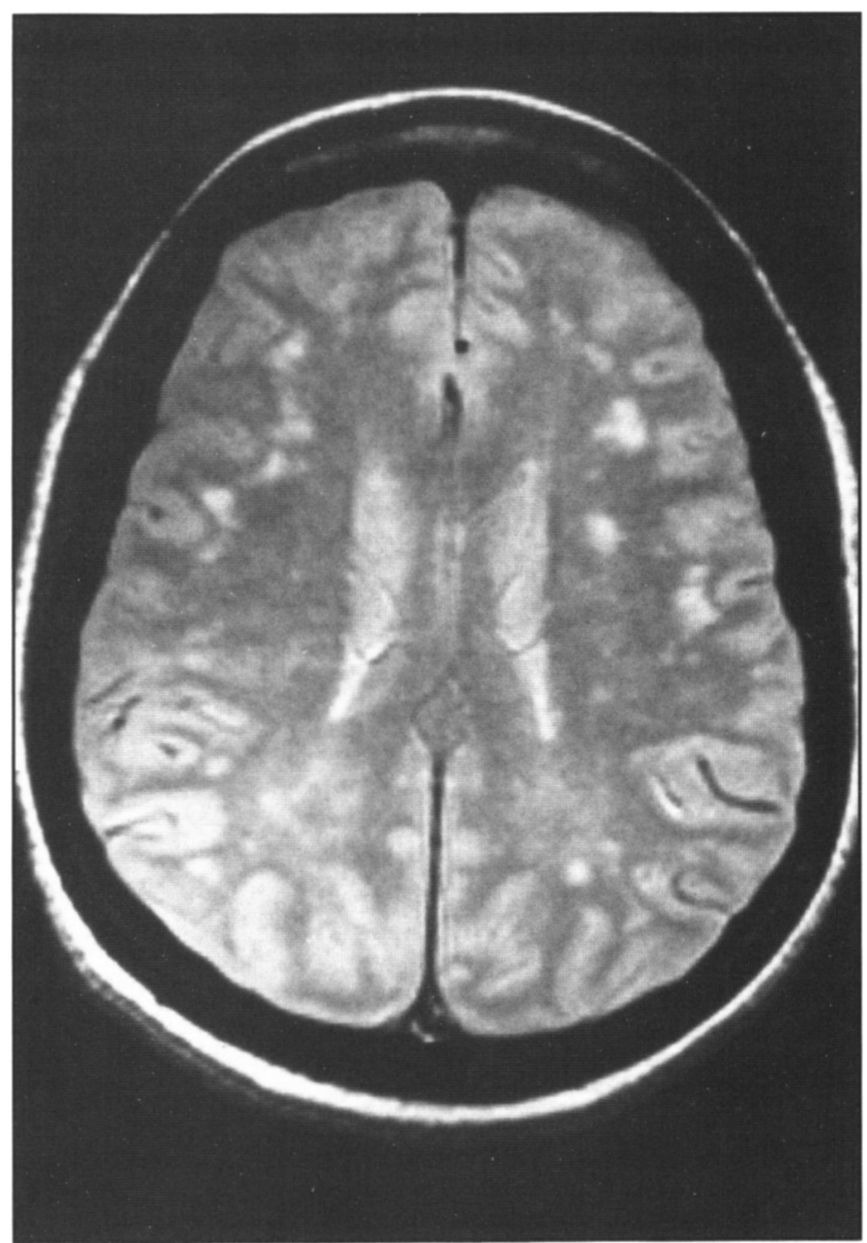

$\mathbf{R}$

Figure 2 - Cranial Scan of Patient 5. (MRI, T2 image) Periventricular white matter lesions show increased signal intensity.

\section{Patient 6}

This 28-year-old Haitian born woman moved to Montreal at the age of 12. She presented with a four year history of progressive myelopathy, associated with mild urinary frequency and mild lower extremity pain. The family history was not contributory and she had not received transfusions.

Physical examination revealed only a moderate spastic paraparesis. and minimal sensory findings.

\section{INVESTIGATIONS}

\section{Imaging}

All patients underwent a cranial MRI (General Electric; 1.5 Tesla). Patients 1, 3 and 5 showed periventricular and subcortical high intensity signals which were more prominent on T-2 weighted images. The most dramatic of the lesions observed are shown in Figures 1 and 2 (Patients 1 and 5, respectively). Patient 3 had very minimal lesions in a periventricular distribution on T2 weighted images (not shown). The others were normal. Spinal cord imaging was normal in all patients.

\section{Electrophysiology}

The first four patients underwent extensive electrophysiological testing. 


\begin{tabular}{lcccc}
\hline Table 1: Cerebrospinal Fluid Findings & & & \\
\hline \hline Patient & $\mathbf{1}$ & $\mathbf{2}$ & $\mathbf{5}$ & $\mathbf{6}$ \\
\hline Cells & 0 & 0 & 0 & 0 \\
Increased Ig index & + & + & + & + \\
$\begin{array}{l}\text { Oligoclonal bands } \\
\text { HTLV-1 Antibody }\end{array}$ & + & + & + & - \\
$\quad$ CSF Titer & 32 & 32 & NT & NT \\
$\quad \begin{array}{l}\text { Titer in Serum } \\
\text { (diluted to IgG concentration } \\
\quad \text { of CSF) }\end{array}$ & 16 & 256 & NT & NT \\
\hline
\end{tabular}

Visual evoked potentials (VEP), determined by averaging the cortical potential between the inion (G1) and the vertex (G2) following a checkerboard visual stimulus, were normal in all patients. Brainstem auditory evoked potentials (BAEP), reflecting the averaged potential recorded between the earlobe (Gl) and the vertex (G2) following contralateral stimulation (1000 clicks), suggesting a pontine delay in the first patient but were normal in the other three patients.

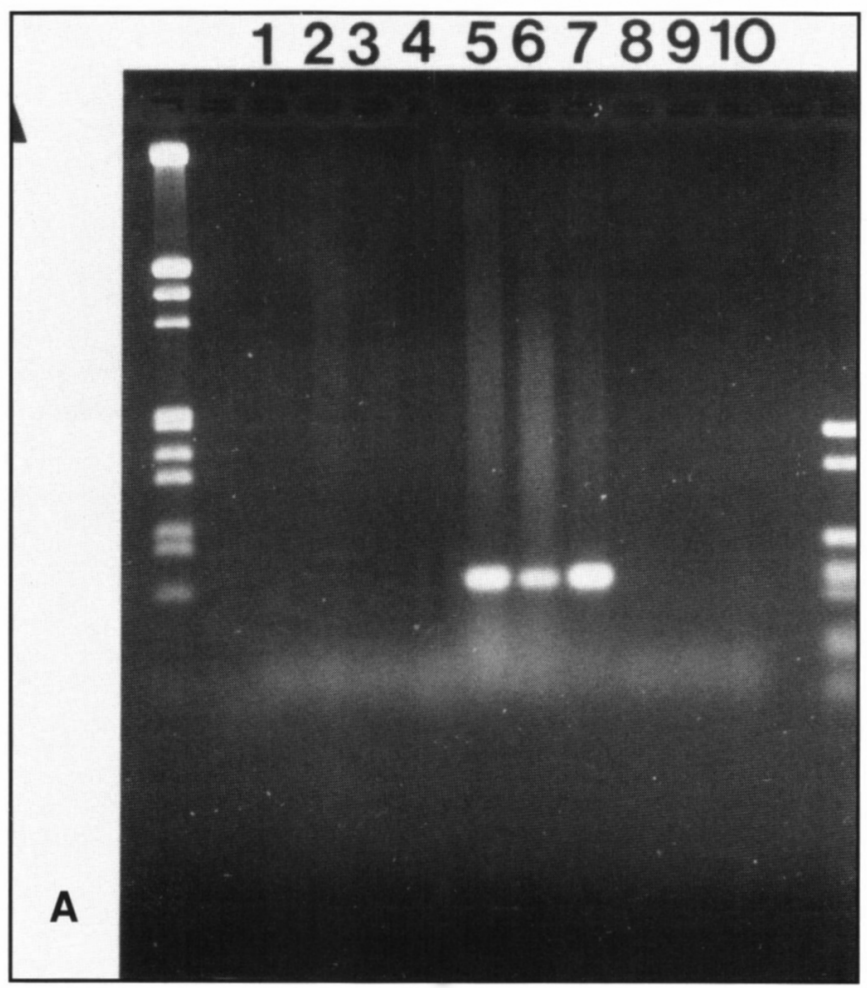

Figure 3 - Southern Blot of Amplification Products.

Figure 3 - a) Ethidium bromide stained gel. The amplified products were separated by agraose gel electrophoresis, and stained with ethidium bromide. The lane assignments are shown below:

1 - Normal Control

2 - Normal Control

3 - Parkinson's disease

4 - Parkinson's disease

5 - Case 1; TSP

6 - Case 2: TSP

7 - HUT-102; an HTLV-1 producing cell line

8 - Sham extracted DNA

9 - Sham extracted DNA

10 - Control for amplification reagents.
Somatosensory evoked potentials (SSEP) were averaged over the parietal scalp, the C7 spinous process, and the upper arm, following stimulation of the median nerve at the wrist. No abnormalities were identified, in keeping with the paucity of sensory symptoms.

Motor evoked potentials (MEP) were recorded over the hypothenar eminence following magnetic stimulation of the scalp (Cadwell stimulator) on the contralateral side and supramaximal stimulation of the neck (cathode at $\mathrm{C} 8$, anode at $\mathrm{C} 6$ ). The difference in latency between these two stimulation points allowed an estimation of central conduction time. MEP were delayed in patients 1 (10.3 msec.), 2 (12.3 $\mathrm{msec}$.) and 3. $(9.3 \mathrm{msec}$.) (normal: $6.0+0.9 \mathrm{msec}$.).

EMG revealed chronic denervation in upper and lower extremities in patients 2 and 3, and in the lower extremities of patient 4 . Denervation was inferred by the demonstration of large complex motor units, fibrillation potentials and positive sharp waves.

Nerve conduction studies were normal in all patients.

\section{Serology}

IgG antibodies specific to HTLV-1 were measured with a commercial ELISA kit and by immunoblot (Dupont, Wilmington, Delaware). Sera from patients 1-5 were positive in both assays. The serum from patient 6 was negative, even when studied at a dilution of $1: 10$.

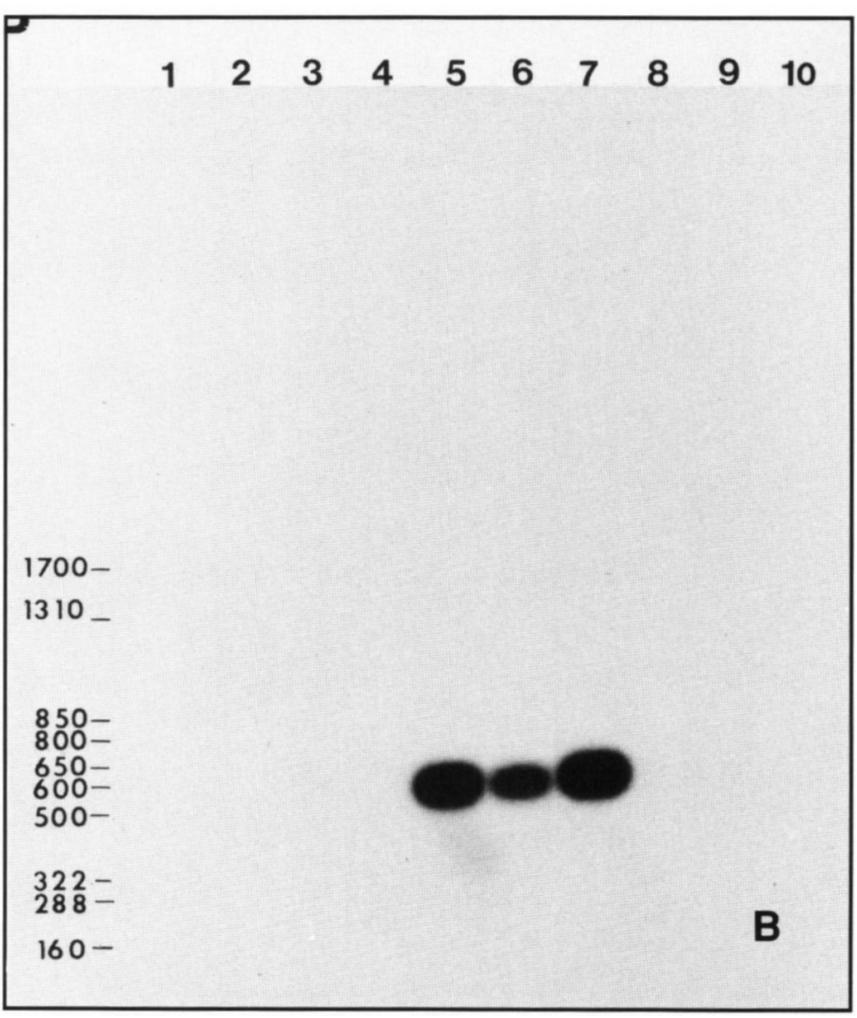

Figure 3 - b) Autoradiogram of Southern blot - The DNA fiom the agarose gel was transferred to nylon paper, and probed for bases complementary to the HTLV-1 p24 gene. The autoradiogram was exposed $36 h$. The lane assignment is the same. 


\section{Cerebrospinal Fluid (CSF)}

CSF was obtained from patients $1,2,5$ and 6 . The findings are summarized in Table 2 . The samples were generally acellular, with increased IgG-albumen ratios. Oligoclonal bands were detected in three.

Antibody titres to HTLV-1 were compared in CSF and serum diluted to the same IgG concentration as CSF in the first two patients (Table 1). The titer of antibody of CSF did not suggest intrathecal antibody synthesis. The amount present was more indicative of the normal partition between the blood and CSF compartments.

\section{Molecular Biology}

DNA was evaluated for the presence of genomic HLTV-1 sequences following amplification by polymerase chain reaction (PCR). High molecular weight DNA was extracted from $50 \mathrm{x}$ $10^{6}$ lymphocytes, which had been purified on Ficoll Paque gradients. ${ }^{10}$ The oligonucleotides used to prime the PCR were derived from sequences in the HTLV-1 p24 gene. The 5' oligonucleotide spanned nucleotide positions 1210-1244 and the $3^{\prime}$ oligonucleotide spanned 1794-1833 according to published sequence. "The oligonucleotide probe used to detect the amplified fragment was located between position 1564-1594. The oligonucleotides were synthesized on an Applied Biosystems Oligonucleotide Synthesizer, (Model 380). The oligonucleotides were purified as described. ${ }^{12}$ The PCR was performed on $1 \mu \mathrm{g}$ of DNA with the Perkin Elmer Cetus GeneAmp DNA amplification kit. ${ }^{13}$ The sample DNA was denatured at $92^{\circ} \mathrm{C}$ for $70 \mathrm{~s}$, annealed at $55^{\circ} \mathrm{C}$ for $120 \mathrm{~s}$, and extended at $72^{\circ} \mathrm{C}$ for $120 \mathrm{~s}$ for the first ten cycles, after which each cycle was extended by $18 \mathrm{~s}$. Each sample was subjected to $30-40$ cycles of amplification, with a thermocycling device (Perkin-Elmer). Controls included sham extracted DNA, the amplification reagents alone, and DNA from normal controls and patients with other neurological diseases. The reaction was terminated by extraction in an equal volume of chloroform and the reaction products were then separated on a $1 \%$ agarose gel. The DNA was transferred to Zeta probe nylon by the method of Southern. ${ }^{14}$ The oligonucleotide probe was end-labelled with gamma ${ }^{32} \mathrm{P}$ - ATP (Amersham, $3000 \mathrm{Ci} / \mathrm{mmol}$ ) and $\mathrm{T} 4$ polynucleotide kinase (Amersham) to a specific activity of $4 \times 10^{9} \mathrm{cpm} / \mu \mathrm{g}$. The blot was prehybridized in 5 X SCC, $10 \times$ Denhardt's buffer, $40 \mu \mathrm{g} / \mathrm{ml}$ herring sperm DNA and $7.0 \%$ SDS at $55^{\circ} \mathrm{C}$ for 6 hours. The blots were then hybridized with $8 \times 10^{8}$ counts of end-labelled probe at $55^{\circ} \mathrm{C}$ for 18 hours. The blot was washed twice in $3 \mathrm{X} \mathrm{SSC}, 10 \mathrm{X}$ Denhardt's, 5\% SDS, $25 \mathrm{mM} \mathrm{NaH}_{2} \mathrm{PO}_{4}$, pH 7.5, for 30 minutes at $65^{\circ} \mathrm{C}$, and then for 30 minutes in $1 \mathrm{X} \mathrm{SSC}$ and $1.0 \%$ SDS at $65^{\circ} \mathrm{C}$. Autoradiograms were prepared by exposing the paper to Kodak XAR-5 $x$-ray film with an intensifying screen at $-70^{\circ} \mathrm{C}$ for 24-36 hours.

A 623 base nucleotide from the HTLV-1 gag gene was amplified from all 5 patients tested (patient 3 not studied). An example of this is shown in Figure 3. In the top portion of this figure, the appearance of the ethidium bromide stained agarose gel is shown. The autoradiogram showing the hybridization of the p24 probe to the amplified products, after transfer from agarose to nylon paper, is shown in the lower figure. The same band was not identified in lymphocyte DNA from healthy laboratory workers or in patients with Parkinson's disease. An iden- tical band was amplified DNA extracted from an HTLV-1 producing cell line, HUT-102. The amplification reagents did not produce this band either alone or from sham extracted DNA, thus excluding contamination by HTLV-I DNA.

Similar results were obtained with amplification of HTLV-1 p19 and reverse transcriptase genes (not shown).

\section{TreatMenT}

Patients 1 and 2 were treated with intravenous methylprednisolone ( $500 \mathrm{mg}$ daily for 5 days), followed by a tapering dose of prednisone. Patient 3 was treated with oral prednisone $80 \mathrm{mg}$ daily for 7 days followed by a tapering course of prednisone. There was no objective improvement. The others were not treated.

\section{Discussion}

Our patients closely resembled the classic descriptions of TSP. ${ }^{1}$ TSP is characterized by insidiously progressive leg weakness, back pain, dysesthesias of the feet, and bladder and bowel dysfunction. The average age of onset is 40 years (range 6-75). Physical examination reveals a spastic paraparesis with brisk deep tendon reflexes and extensor plantar responses. Cranial nerve dysfunction (optic neuritis and deafness) is uncommon, and sensory findings are less prominent than in spinal forms of multiple sclerosis. Mild involvement of peripheral nerves has been described, and a myositis may rarely complicate the condition. ${ }^{15}$ Cognitive changes have not been described.

HTLV-1 associated myelopathy is common in a number of regions in the world. In Martinique, 78 percent of the patients with this progressive myelopathy are seropositive for HTLV-1, compared to a general population prevalence of 4 percent. ${ }^{16}$ Japanese patients with this chronic myelopathy are uniformly seropositive for HTLV-1; in the Kii peninsula the general seropositivity is 16 percent. ${ }^{17}$ The prevalence of HTLV-1 seropositivity in the United States is estimated to be 0.025 percent and appears to be concentrated in blacks in the south eastern United States, especially in intravenous drug users, and their sexual partners. ${ }^{18}$

Because five of our 6 patients originated in areas endemic for HTLV-1 infection, an HTLV-1 etiology for their myelopathies was not surprising. Patient 5 , however, had originated from Chile, where TSP has not yet been described. Furthermore, multiple sclerosis is uncommon in Chile. ${ }^{19}$ She developed symptoms of her myelopathy a decade after immigration to Canada. Because her spouse did not have evidence of HTLV-1 infection, one could infer the possibility of vertical transmission. Her parents have not yet been studied.

We were intrigued by the absence of virus-specific antibody in patient 6, even though the HTLV-1 p24 gag gene could be easily amplified from leukocyte DNA. This patient had no evidence of antibody to HIV-1, and no reason to suggest another cause for her myelopathy. It is well recognized that some retroviral infections do not incite an antibody response. 20 In many of the epidemiological studies of TSP, not all patients have been shown to have antibody, despite the application of methods which are generally sensitive. ${ }^{2}$

Myelopathy appears to be a relatively uncommon expression of HTLV-1 infection. It affects between 1:100 and 1:1000 indi- 
viduals infected with this virus, although long-term follow-up of infected individuals is lacking. ${ }^{21}$ It seems to occur in a different subset of individuals than those predisposed to adult T-cell leukemia. Coincidental cases are only rarely described. ${ }^{22}$ The factors which promote expression of myelopathic phenotype are far from clear. Usuko has suggested that HLA type is important, but more studies are needed. 23

Our patients had progressive myelopathies, positive oligoclonal bands in spinal fluid and 3 of 6 had radiologic evidence of CNS dissemination. The potential for confusion with multiple sclerosis, especially spinal forms, is obvious and diagnostic criteria for both conditions will need revision. Four of these patients were referred because they were thought to have multiple sclerosis. Caucasian extraction, major sensory findings, and absence of peripheral nerve signs favour a diagnosis of multiple sclerosis. Indeed a virus related to HTLV-1 has been raised as an etiological possibility in multiple sclerosis, ${ }^{24}$ but this remains controversial. 9.25

The pathogenesis of the myelopathy is a mystery. The few neuropathological studies have demonstrated demyelination in the dorsal and lateral funiculi, some axonal loss, and variable degrees of vacuolation and inflammation. ${ }^{26}$ Demyelination in plaques has not been described. Virus gene products have not been well characterized within the CNS. Direct CNS infection, or a virus-altered immune response, or both, could explain the syndrome, but no data are currently available. Preliminary observations suggest that virus genes can be amplified from spinal cord, but not other parts of the nervous system. There is a correlation between the distribution of the pathology, as seen by light microscopy, and the ability to retrieve retroviral genes by gene amplification (unpublished observations).

We found inflammatory cells and increased $\mathrm{IgG}$ in the spinal fluid. Virus-specific antibody was found in both compartments, but the CSF/serum ratio did not suggest a major component of intrathecal antiviral antibody synthesis, as suggested by others. ${ }^{27}$ Perhaps the IgG is directed at other antigens (possibly self or virus-altered self). A treatment for TSP has not been established. Our patients did not respond to corticosteroids. Further studies are perhaps warranted with agents similar to those deployed in patients with other retroviral infections of the CNS, such as AIDS.

The finding of 6 TSP cases in Canada has important epidemiological implications. All developed their myelopathy in Canada, although they were likely exposed to this agent in the countries from which they emigrated. Patient 5 originated from Chile, which is not endemic for this infection, although her husband had travelled through endemic parts of South America. Neurologists in Canada and other countries with temperate climates should be wary of HTLV-1 in the differential diagnosis of all patients with chronic myelopathy.

If there are approximately 100 seropositive individuals for each patient with myelopathy, ${ }^{21}$ the prevalence of HTLV-1 seropositivity in Canada might be greater than expected. The virus is transmitted by transfusion, sexual contact, and can be vertically transmitted, from mother to child. A cross-sectional survey of HTLV-1 seropositivity in Canada might have an important bearing on current blood screening practices.

\section{ACKNOWLEDGEMENT}

Brian G. Weinshenker is a postdoctoral fellow of the Canadian Multiple Sclerosis Society. George A. P. Rice is a career scientist of the Ministry of Health of Ontario. This study was supported by the Multiple Sclerosis Society of Canada. Donna Greer provided expert assistance with preparation of the manuscript, and Paul Payson and Elaine Kinghorn provided excellent technical support.

\section{REFERENCES}

1. Cruickshank EK. A neuropathic syndrome of uncertain origin: a review of 100 cases. West Indian Med J 1956; 5: 147-158.

2. Gessain A, Barin F, Vernant JC, et al. Antibodies to human T lymphotropic virus type I in patients with tropical spastic paraparesis. Lancet 1985; ii: 407-410.

3. Roman GC, Roman LN, Spencer PS, Schoenberg BS. Tropical spastic paraparesis: a neuroepidemiological study in Colombia. Ann Neurol 1985; 17: 361-365.

4. Roman GC, Spencer PS, Schoenberg BS, et al. Tropical spastic paraparesis in the Seychelles Islands: a clinical and case control neuroepidemiologic study. Neurology 1987; 37: 1323-1328.

5. Roman GC. The Neuroepidemiology of Tropical Spastic Paraparesis. Ann Neurol 1988; 23 (supp): S113-S120.

6. Osame $\mathrm{M}$, Matsamuto $\mathrm{M}$, Usuka $\mathrm{K}$, et al. Chronic progressive myelopathy associated with elevated antibodies to HTLV-1 and adult T-cell leukemia-like cells. Ann Neurol 1987; 21: 117-122.

7. Jacobson S, Raine CS, Mingioli ES, MacFarlin D. Isolation of an HTLV-1-like retrovirus from patients with tropical spastic paraparesis. Nature 1988; 331: 540-543.

8. Bhagavati S, Ehrlich G, Kula R, et al. Detection of human T-cell lymphoma/leukemia virus type I DNA and antigen in spinal fluid and blood of patients with chronic progressive myelopathy. N Engl J Med 1988; 318: 1141-1147.

9. Weinshenker BG, Rice GPA. Retrovirus diseases of the nervous system. In: Demyelinating Diseases of the Nervous System. Ed. S Kim Plenum (in press).

10. Canaani E, Aaronson SA. Restriction enzyme analysis of mouse cellular type-C viral DNA: emergence of new viral sequences in spontaneous AKR/J lymphomas. Proc Natl Acad Sci USA 1974; 77: 5579-5783.

11. Seiki M, Seisuke H, Hirayama Y, Yoshida M. HTLV-1 virus: complete nucleotide sequence of the provirus genome integrated in leukemia cell DNA. Proc Nat Acad Sci 1983; 80: 3618-3622.

12. Clark P, Lin HC, Wilcox G. Ultraviolet imaging: A simple method for detecting nucleic acids in preparative gels. Analytical Biochem 1982; 124: 14-22.

13. Saiki R, Gelfand D, Stoffel S, et al. Primer-directed enzymatic amplification of DNA with a thermostable DNA polymerase. Science 1988; 239: 487-494.

14. Southern EM. Detection of specific sequences among DNA fragments separated by gel electrophoresis on nitro-cellulose. J Mol Biol 1975; 38: 503-517.

15. Goudreau G, Karpati G, Carpenter S. Inflammatory Myopathy in Association with Chronic Myelopathy in HTLV-1 Seropositive Patients. Neurology 1988; 38 (suppl): 206.

16. Vernant JC, Maurs L, Gessain A, et al. Endemic tropical spastic paraparesis associated with human T-lymphotropic virus type I: a clinical sero-epidemiological study of 25 cases. Ann Neurol 1987; 21: 123-130.

17. Osame M, Usuku K, lzumo $S$, et al. HTLV-1 associated myelopathy: a new clinical entity. Lancet 1986; i: 1031-1032.

18. Williams AE, Fang CE, Slamon DJ et al. Seroprevalence and epidemiological correlates of HTLV-1 Infection in U.S. Blood Donors. Science 1988; 240: 643-646.

19. Alvarez G, Cardenas $M$. Multiple sclerosis following optic neuritis in Chile. J Neurol Neurosurg Psychiatry 1989; 54: 115-117. 
20. Loche M, Mach B. Identification of HIV-infected seronegative individuals by a diagnostic test based on hybridization to amplified viral DNA. Lancet 1988; ii: 418-420.

21. Saida T. HTLV-I associated myelopathy in Japan. International Symposium on Retrovirus in multiple sclerosis and related disease. Copenhagen.

22. Bartholomew C, Cleghorn F, Wavenay C, et al. HTLV-1 and Tropical Spastic Paraparesis 1986. Lancet; ii: 9-10.

23. Usuko K, Sonoda S, Osame M, et al. HLA haplotype linked high immune responsiveness against HTLV-1 in HTLV-1 Associated Myelopathy: comparison with Adult T-cell leukemic/lymphoma. Ann Neurol 1988; 23 (suppl): 5143-159.

24. Koprowski H, DeFreitas EC, Harper ME, et al. Multiple sclerosis and human T-cell lymphotropic retroviruses. Nature 1985; 318: $154-160$.
25. Rice GPA, Armstrong HA, Bulmer DE, et al. Absence of antibody to HTLV-1 and III in sera of Canadian patients with multiple sclerosis and chronic myelopathy. Ann Neurol 1986; 20: 533534.

26. Robertson WB, Cruickshank EK. Jamaican (tropical) myeloneuropathy. In: Minkler 3 ed. Pathology of the Nervous System. Vol. 3 New York: McGraw, 1972; 2466-2476.

27. Gessain A, et al. Intrathecal synthesis of antibodies to Human $T$ Lymphotropic Virus Type I and the presence of IgG oligoclonal bands in cerebrospinal fluid of patients with endemic Tropical Spastic Paraparesis. J Infect Dis 1988; 157(6): 1226-1234. 